conservation of matter, a philosophical predecessor of Spinoza, the great liberal Cardinal Nicolaus Cusanus, was a student at Heidelberg and wrote the famous "De pace fidei". It is sometimes said that Germany has returned to the Middle Ages. Would that she had returned to the Middle Ages as represented by the Cardinal who is perhaps the greatest of the children of the University of
Heidelberg. The Heidelberg Academy is or was in the course of publishing the works of Cusanus. This has not prevented the authorities at Heidel. berg from acting in a spirit utterly opposed to that of Cusanus, and unseemly incidents, prompted by dem deutschen Geist, are occurring even in connexion with the issue of the works of Heidelberg's illustrious son.

\title{
Obituary
}

\section{Prof. J. H. Ashworth, F.R.S.}

$\mathbf{J}^{\mathrm{A}}$ AMES HARTLEY ASHWORTH was born in Accrington, brought up in Bolton, Lancashire, and educated at Owen's College, Manchester. It was his intention to specialise in chemistry, but he transferred to zoology. He was trained under A. Milnes Marshall and C. H. Hurst and later under S. J. Hickson, all outstanding zoologists and excellent teachers. His marked ability soon became apparent, for he obtained the Dalton prize in natural history, graduated B.Se. of London at the age of twenty-one years, and four years later obtained the D.Se. of the same University. From 1896 until 1900 he held the post of junior lecturer and demonstrator in zoology at Manchester. He then spent some time at the Biological Station at Naples, and the large amount of material he collected there is evidence of his zeal and enthusiasm. The visit impressed him deeply, and he retained an affection for the Station and the zoologists he met there. Until his death he was chairman and secretary for the British Association table at Naples. He was for many years the recorder of Section D (Zoology) of the Association and was president of the Section in 1923.

In 1901 Ashworth was appointed lecturer in invertebrate zoology at Edinburgh. Four years later the University instituted a diploma in tropical medicine, and such was the trust reposed in him that he was asked by the medical faculty to conduct a course in entomology and parasitology for this diploma. This was no easy task, since it was the first course of its kind to be given in Britain. $\mathrm{He}$ threw himself wholeheartedly into the work and brought to bear on it his extensive knowledge of invertebrate zoology, his teaching skill and his interest in the relationship between zoology and medicine. The course achieved conspicuous success, and from the beginning set a high standard which it has since maintained. His title now became lecturer in medical entomology and parasitology. Later, helminthology was added to the course, which was modified to furnish the basis of instruction for the diploma in public health and the diploma in tropical veterinary medicine. Students who attended these classes have come from, and are to be found in, all parts of the world. It must have been gratifying to Ashworth that so many of his former students came to visit him when on leave and kept in touch with him by correspondence. A number of them presented specimens, often illustrative of their own special lines of investigation, so that he built up an excep. tionally complete teaching collection. All of this testifies to the affectionate gratitude that he inspired in his students.

In spite of heavy teaching duties, Ashworth pub. lished a number of important researches. The earlier ones were concerned with coelenterates and marine worms, but the later included Protozoa and helminths. These papers are characterised by meticulous care and accuracy of observation, by clear and concise exposition, and are illustrated by drawings showing more than ordinary skill. The paper on "The Habits and Structure of Arenicola marina" (Quart. J. Micro. Sci., 1898), written conjointly with F. W. Gamble, was the precursor of a series of publications on Polychætes, including the memoir on Arenicola in the Liverpool Marine Biological Com. mittee Series, which is used in zoological laboratories throughout the world. He became the recognised authority on his group and was asked to write the catalogue of the Chætopoda in the British Museum, A, Pt. I, Arenicolidæ. His work on the group was by no means confined to systematics but included noteworthy contributions to anatomy and histology, particularly the paper on "The Giant Nerve Cells and Fibres of Halla parthenopeia" (Phil. Trans. Roy. Soc., 1909). His eminence in research led to his election to the Royal Society of Edinburgh in 1911 (of which he was general secretary when he died), to the Royal Society of London in 1917, and to the award of the Keith medal of the former Society in 1916.

Ashworth early realised that the accommodation and arrangements for the teaching of zoology in the University were hopelessly inadequate, and when in 1919 he was made professor of zoology, he saw the opportunity for remedying this state of affairs. He set before himself two aims and devoted himself steadfastly to their accomplishment. They were the building up of a staff, laboratories and equipment suitable for giving a satisfactory course in general zoology, and secondly, increasing the usefulness and raising the standard of the classes in zoology for medical students, both undergraduate and graduate, 
to a level worthy of the traditions of a famous medical school.

A generous donation from a personal friend, the late Mr. Lawrence Pullar of Bridge of Earn, formed the nucleus for the provision of a new department, and largely owing to Ashworth's energy and personality the necessary funds were raised. He visited many laboratories at home and in America to gather ideas for use in planning a new department. In 1927 he succeeded Cossar Ewart in the chair of natural history, and in 1929 one of his objects was achieved when H.R.H. Prince George opened the new laboratories at West Mains Road. This building was the result of careful thought, and the successful way in which it fulfils its purposes is a tribute to Ashworth's marked skill in organisation. The second object was always present in his thoughts, and not a year passed that did not see an improvement in the medical courses.

Ashworth's grasp of detail, the care with which he studied any matter requiring his attention, his sound judgment and courteous consideration for the opinions of others, enabled him to fill many executive positions in the University and in learned societies with outstanding efficiency. As a teacher he was most conscientious, painstaking and successful, and his devotion to his work was a source of inspiration to all connected with him. While his own research was in the domain of invertebrate zoology, his catholic reading and retentive memory made him at home also in vertebrate work, and there are few zoologists with such an all-round knowledge. The department is enriched by specimens he brought back from two visits to America, one to South Africa and one to Australia. To his students, colleagues and friends he gave ungrudgingly of his best, and his sudden death on the morning of Tuesday, February 4, came to them all as a deep personal loss. NATURE itself loses a constant friend, whose contributions and advice over a long period of years have been of the greatest value.

In his earlier life, Ashworth played the piano and always retained a love of music. He was a sincere and kindly man whose charm of manner and engaging personality won him many friends. He is survived by his widow, who throughout his life in Edinburgh shared his labours and achievements.

\section{Mr. R. Southern}

THe sudden and unexpected death, on December 13 in Dublin, of Mr. R. Southern, has taken away one of the keenest and most thorough students of fresh-water biology in its relation to fisheries in the British Isles.

Rowland Southern was born in 1882 at Adlington in Lancashire, and, after an early training in chemistry, obtained a post, in 1902, in the office of the City Analyst in Dublin. His natural bent was, however, towards biology, and in 1906 he received an appointment in the Natural History Section of the Irish National Museum, resigning this post in 1911 for one in the Fisheries Branch of the Department of Agriculture and Technical Instruction.
During his time in the Museum, Southern took up the study of annelids and other worms, and, in a short time, made himself a recognised authority. $\mathrm{He}$ continued this study while engaged in the general fishery work of the Department, publishing, at frequent intervals, papers on the various groups, mainly based on his own observations and collections.

During the Great War, Southern's application for active service having been rejected on the grounds of short sight, he was for a time in charge of the Department's efforts to promote increased utilisation of fresh-water fish as a source of food. This gave a now direction to his interests. In 1920, a Limnological Laboratory, the first adequately equipped fresh-water station in the British Isles, was established on the River Shannon close to Lough Derg, under the control of the Department, with the aid of funds supplied by the Development Commissioners, and he was put in charge. From that time, the study of fresh water biology, mainly in its ecological aspect, was his chief preoccupation. It was in the course of his work on Lough Derg that his attention was directed to the difference in size of trout in acid and limestone waters, and the search for an adequate explanation formed the background of all his subsequent investigations, for the cause usually alleged, that of more abundant food in the alkaline waters, did not, as he pointed out, agree with the facts.

At the closure of the Limnological Laboratory in 1923, Southern's headquarters were transferred to Dublin and, with the problem of growth-rate in his mind, he planned an intensive survey of the productivity in fish food of the River Liffey and its tributaries by means of periodic quantitative collections during several years, both from the upper peaty waters and the lower limestone reaches. $\mathrm{He}$ also instituted the regular collection of salmon scales from the River Shannon, in order to elucidate the age and growth-rate of the fish in that river in connexion with the changes brought about by the new hydro-electric scheme. At the time of his death he was working on the collection of salmon scales, on which he had already published a first report, and was tabulating the results of the examination of an immense amount of material from the River Liffey, mainly insect larvæ, collected and named by himself and his willing helpers.

Southern's biological work, latterly, was done, for the most part, in his spare time, as his official hours were largely occupied by his manifold duties as an inspector dealing with the inland fisheries of the Irish Free State. He was an enthusiastic and expert angler and his knowledge, from practical experience, of the angling waters of Ireland, was unrivalled, and was freely put at the disposal of all inquirers at his official headquarters.

Southern was a frequent attendant at the meetings of the International Council for the Exploration of the Sea, as an expert on behalf of the Irish Free State, and was an active member of the Salmon and Trout Committee of that body. His death, in the midst of his work, leaves many friends in scientific and angling circles in Ireland and elsewhere to regret his loss.

G. P. F. 